\title{
Effect of Massage Therapy in Cancer Patients in Palliative Situation
}

\author{
Marcia Alves ${ }^{1, *}$, Maria Helena de Agrela Gonçalves Jardim², Bárbara Pereira Gomes ${ }^{3}$ \\ ${ }^{1}$ Abel Salazar Institute of Biomedical Sciences, University of Porto, Portugal \\ ${ }^{2}$ Center for Health Technologies (CTS), University of Madeira, Portugal \\ ${ }^{3}$ School of Nursing of Porto, Portugal
}

Copyright $\mathrm{O} 2017$ by authors, all rights reserved. Authors agree that this article remains permanently open access under the terms of the Creative Commons Attribution License 4.0 International License

\begin{abstract}
The increase in longevity and incidence of chronic diseases reveals an increased importance in terms of public health. The oncologic illness is a debilitating and progressive pathology with need for prevention and symptomatic relief. In order to find the answer to the question: "What is the effect of massage therapy in cancer patients?" we have reviewed the empirical literature indexed in databases online, finding only 21 articles published between 1990 and 2015. It was possible to verify some of the effects of massage therapy, particularly in relieving pain, decreased anxiety, depression and nausea and increased well-being. However, it was not found the effect of this intervention on the relief of suffering and the quality of life of patients. With the heterogeneity of methodologies, studies suggest the development of more homogeneous research, materials and methods to assess the effects of massage therapy in cancer patients.
\end{abstract}

Keywords Patients, Oncology, Massage

\section{Introduction}

Massage therapy results in touch and its goals are varied including: the ability to help the body relax, feeling pleasure to overcome physical problems, releasing emotional blocks, and easing of pain among others.

This type of massage is a method of treatment used in curing a disorder. The massage can be applied for therapeutic purposes to assist in restoring the balance of the various human structures. It is also assumed that its application triggers mechanical effects, painkillers, psychological, structural and thermal effects, which are in line with the main purpose of our report.

According to Meleis[18], the purpose of the nurse is to interact with humans in situations of health or disease, to improve the cultural and social context where they are inserted because they are suffering some kind of transition or anticipating the same. As for the nurse-patient interactions, these can be organized around a main purpose and the nurse uses some therapeutic actions to improve, bring or facilitate the patient's health.

In a second phase, with this report, we can analyse the effect of massage therapy on cancer patients. Being so, we have seen the number of patients with psychological changes increase, including depression, which decreases the quality of life of these patients and the depressive symptoms. This can actually generate a bigger limitation than the cancer itself and can cause suicide in about $50 \%$ of the patients. In turn, the anxiety has a prevalence rate of 18-35.1\% (Castro, Scorza \& Chem[7).

Among cancer patients, more than $70 \%$ of them suffer from pain caused by disease and/or by handling. Patients in advanced stages of cancer describe the pain as moderate or severe in approximately 40 to $50 \%$, and, according to Bair et al.[4] in $25-30 \%$ of the patients. In 2004, the Hospice and Palliative Nurse Association has developed a document concerning the pain where it is quoted that this vital sign is one of the most feared by patients in end-of-life. Therefore, it increases the physiological stress and decreases morbidity by adding the risk of thromboembolism in these patients (Runnig, Shreffler-Grant \& Andrews[22]). The skills of nurses can provide care to a patient in chronic condition aimed at caring for the person with the disease, lessening the suffering, maximizing their well-being, comfort and quality of life (Ordem dos Enfermeiros[20]).

Nurses are crucial elements of a multidisciplinary team because they are actively involved in monitoring and pain relief, which requires the screening of the psychological, cognitive and emotional components of pain, including anxiety, depression and grief. Nurses also have previous experience in dealing with the pain, lack a personal, cultural and spiritual influence and can advise the prescription of non-pharmacological interventions in complementarity but not in replacement of pharmacological therapy, knowing their indications, contraindications and side effects (Ordem dos Enfermeiros[19]; Direção Geral de Saúde[10]). 
The massage can be curative and preventive, as it can rehabilitate and relief of muscle tension. Patients who benefit from these interventions exhibit lower levels of anxiety and pain, having more control over treatment decisions (Almeida e Duarte[3]).

Based on the assumption that massage is beneficial to improve the patient's health condition, this literature review has found answers for the question "what is the effect of massage therapy on cancer patients?". Being so, the conclusion is that the purpose of the analysis conducted in this topic was achieved.

\section{Methodology}

This research was based on a systematic review of the literature with narrative summary. It was held exclusively in online databases, including EBSCOhost (Medline, Cochrane
Central Register of Controlled Trials, Cochrane Database of Systematic Reviews, Psychology and Behavioural Sciences Collection, EJS E-Journals, and British Nursing Index), SciELO and RCAAP (open access Scientific Repository of Portugal). As inclusion criteria, we consider articles reported in the period between 1990 and 2015, in full-text and about massage therapy in adult patients with medical diagnosis of cancer. The articles that didn't report the investigation around the theme under study and that did not present the predefined inclusion criteria were deleted.

The research selected 120 articles, including 50 articles on EBSCOhost, 10 on Scielo and 60 in RCAAP, through the keywords for palliative care, oncology, cancer and massage therapy. Some articles had common databases and after full thorough reading, 21 studies were selected for systematic review. The remaining articles have been removed for not meeting the inclusion criteria (table 1).

Table 1. Reduction scheme

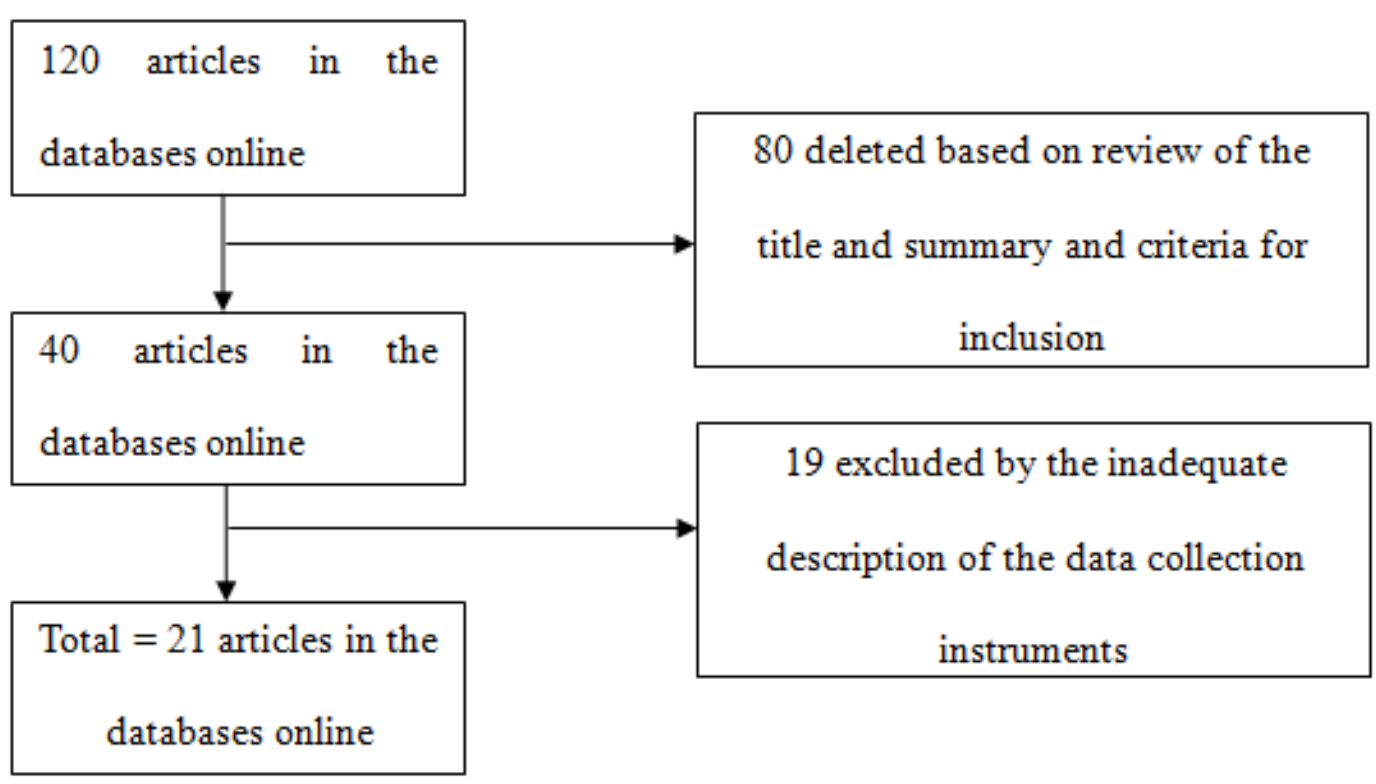


After an analysis and synthesis of selected articles, a summary table was created contemplating information extracted from each article and a descriptive analysis of the results.

\section{Results}

The synopsis of the articles and selected studies was described under paragraph 1 , in accordance with the year of publication, study goals, type of study, methods, and results. In relation to the year of publication, it was identified the prevalence of studies published in 2004, 2007 and 2008, with 3 articles each. 2 articles were published in the years 2000 , 2003 , and 2009, and the rest only obtained a publication for each date mentioned. It was observed that the intervention of massage therapy in oncology nursing professionals offers a limited number of researches, although with some concern over the past fifteen years. Methodologically, it was found that the majority of studies are the quantitative paradigm. The most commonly data collection instruments used was the Visual analogue scale (EVA) for the assessment of symptoms, including pain, anxiety and nausea. It was also observed the use of scale Brief Pain Index (BPI) for the assessment of pain and State-Trait Anxiety Inventory (STAI) for evaluation of anxiety. Only one article used mixed qualitative and quantitative methodology, combining the EVA and the interview as methods. Through the analysis of the results of the studies selected, we categorized them according to the focus of nursing - (Classificação Internacional para a Prática de Enfermagem - CIPE), including pain, anxiety, depression, discomfort and suffering.

Taking into account the main results, it can be enhanced that massage therapy reduces: immediate levels of pain in male cancer patients (Weinrich \& Weinrich[26]), pain levels of approximately $50 \%$ plus an improvement of $10 \%$ in sick bay rather than in the relocation and more durability of such reduction in pain (Cassileth \& Vickers[6]), the intensity of the pain between $60 \%$ (Ferrell-Torry \& Glick[13]) and $42 \%$ (Wilkie et al.[27]), as well as its average decrease of 5.50 to 3.83 (Toth et al.[25]) and 5.18 to 2.33 values (Adams, White $\&$ Beckett[1]). Also, through the qualitative results enhance improvements of total pain (Adams et al. [1]). This procedure significantly reduces the levels of pain (Post-White, Kinney, Savik, Gau \& Lerner[21]; Currin \& Meister[8]; Young[29]), either immediately (Grealish, Lomasney, \& Whiteman[14]; Kutner, Smith, Corbin, Kemphill, Benton \& Mellis[17]; Sui-Whi, et al.[24]), short-term (20/30 minutes) and long term (16/18 hours) (Sui-Whi, et al.[24]), although the most significant impact occurred in the first few minutes after the intervention (Jane et al.[16]). It also showed a decrease in analgesics used and consumption of rescue analgesics (Post-White, Kinney, Savik, Gau \& Lerner[21]; Deng \& Cassileth[9]), although the consumption of morphine was held for 10 days. Nevertheless, there was a reduction in levels of pain after the 5 th day (Ferreira \& Lauretti[12]). However, there is a study which does not have significant differences that confirms the decline in the use of painkillers (Ferreira \& Lauretti[12]; Kutner et al.[17]). Likewise, it was not shown significant changes in the long term benefits of massage in terms of improvement and pain control (Ferreira \& Lauretti[12]; Kutner et al.[17]). These results corroborate a study, that although there was a decrease of pain, the difference was not statistically significant (Deng \& Cassileth[9]).

As for anxiety, there was a decrease of anxiety with $24 \%$ (Ferrell-Torry \& Glick[13]) and 50\% (Cassileth \& Vickers[6]), however only a study anxiety increased from 3.83 to 4.75 (Toth et al.[25]). Other studies showed a significant reduction in anxiety and depression after massage therapy (Post-White, Kinney, Savik, Gau \& Lerner[21]; Hernandez-Reif, Ironson, Field, Hurley, Katz \& Diego[15]; Cassileth \& Vickers[6]; Deng \& Cassileth[9]; Young[29]; Jane et al. [16])

Massage therapy has immediate effect on reducing depression and anxiety and also long-term depression (Soden, Vincent, Craske[23]; Hernandez-Reif et al.[15]). However, there are studies in which there were no differences in short term between anxiety and depression (Ahles et al.[2]) or that there were no significant differences of depression and anxiety in the long term (Billhut, Bergbom \& Stenes-Victorin[5]). Another study confirms these results, noting that there were no significant differences in improvement of anxiety and depression. However, by structured interviews, the self-report of anxiety has improved for patients who received massage therapy. This relationship did not exist for the self-report of depression (Wilkinson et al.[28]).

As far as the other variables studied, the massage contributes for the immediate reduction of nausea (Ahles et al.[2]; Grealish, Lomasney, \& Whiteman[14]; Cassileth \& Vickers[6]; Billhult et al.[5]), although it was mentioned the non-existence of significant differences of this long-term variable (Ahles et al.[2]; Post-White et al.[21]). It was referred the reduction of blood pressure, heart rate and breathing, indicating the relaxing action of massage therapy (Ferrell-Torry \& Glick[13]; Post-White et al.[21]; Deng \& Cassileth[9]). The complement of this intervention increases the relaxation (Ferrell-Torry \& Glick[13]; Grealish, Lomasney, \& Whiteman[14]; Adams et al.[1]), because they have immediate effect in depressed mood and anger (Hernandez-Reif, Ironson, Field, Hurley, Katz \& Diego[15]; Kutner et al.[17]). This intervention significantly decreases the incidence of muscular fatigue (Cassileth \& Vickers[6]; Deng \& Cassileth[9]; Currin \& Meister[8]), reduces stress (Cassileth \& Vickers[6]) and significantly improves the level of emotional well-being, relaxation and sleep patterns). It adds a significant decrease in dimensions of suffering in pain, physical and emotional discomfort, as well as on fatigue after massage (Currin \& Meister[8]). The quality of life 
significantly improves (Ferreira e Lauretti[12]), but in the that could corroborate the improvement of quality of life, long term there was no statistically significant differences stress and suffering (Kutner et al.[17]; Soden et al.[23]).

Table 2. General characterization of the articles reviewed

\begin{tabular}{|c|c|c|c|c|c|c|}
\hline Author (s) & Date & Goal of the study & Type of study & Methods & Sample & Results \\
\hline $\begin{array}{l}\text { Weinrich, S, \& } \\
\text { Weinrich, M. }\end{array}$ & 1990 & $\begin{array}{l}\text { Evaluate the effect of } \\
\text { therapeutic massage in } \\
\text { the levels of pain }\end{array}$ & experimental & $\begin{array}{l}\text { Visual Analogue } \\
\text { Scale (EVA). }\end{array}$ & $\begin{array}{l}28 \text { cancer } \\
\text { patients }\end{array}$ & $\begin{array}{c}\text {-Decrease of } \\
\text { immediate pain levels } \\
\text { in males and only in the } \\
\text { experimental group }\end{array}$ \\
\hline $\begin{array}{l}\text { Ferrell-Torry, A., } \\
\text { \& Glick, O. }\end{array}$ & 1993 & $\begin{array}{c}\text { Evaluate the } \\
\text { effectiveness of } \\
\text { therapeutic massage in } \\
\text { pain, anxiety, vital } \\
\text { signs and relaxation }\end{array}$ & exploratory & $\begin{array}{c}\text { analogue for pain; } \\
\text { - Spielberger State } \\
\text { Anxiety } \\
\text { Inventory;- TA, } \\
\text { FC, FR }\end{array}$ & $\begin{array}{l}9 \text { cancer } \\
\text { patients }\end{array}$ & $\begin{array}{c}\text {-Reduction of pain in } \\
60 \% \text { and anxiety } X= \\
24 ; \\
\text {-Reduction of vital } \\
\text { signs, indicating its } \\
\text { relaxing action }\end{array}$ \\
\hline $\begin{array}{l}\text { Ahles, T., Tope, } \\
\text { D., Pinkson, B., } \\
\text { Walch, S., Hann, } \\
\text { D., Whedon, M. }\end{array}$ & 1999 & $\begin{array}{c}\text { Analyze the impact of } \\
\text { therapeutic massage in } \\
\text { psychological, physical } \\
\text { and } \\
\text { Psychophysiological } \\
\text { measures }\end{array}$ & experimental & $\begin{array}{c}\text { State-Trait } \\
\text { Anxiety Inventory } \\
\text { (STAI), Beck } \\
\text { Depression } \\
\text { Inventory (BDI), } \\
\text { and Brief Profile } \\
\text { of Mood States } \\
\text { (POMS) }\end{array}$ & $\begin{array}{l}34 \text { patients } \\
\text { awaiting bone } \\
\text { marrow } \\
\text { transplant }\end{array}$ & $\begin{array}{l}\text { It Had immediate effect } \\
\text { on stress reduction, } \\
\text { nausea and anxiety } \\
\text { No significant } \\
\text { difference of these } \\
\text { variables in the long } \\
\text { run }\end{array}$ \\
\hline $\begin{array}{l}\text { Wilkie, D., } \\
\text { Kampbell, J., } \\
\text { Cutshall, S., } \\
\text { Halabisky, H., } \\
\text { Harmon, H., } \\
\text { Johnson, L., et al. }\end{array}$ & 2000 & $\begin{array}{l}\text { Evaluate the effect of } \\
\text { therapeutic massage in } \\
\text { the levels of pain }\end{array}$ & random study & EVA & $\begin{array}{l}29 \text { cancer } \\
\text { patients }\end{array}$ & $\begin{array}{l}\text {-Decrease in pain } \\
\text { intensity at } 42 \% \text { in the } \\
\text { experimental group } \\
\text { and } 25 \% \text { for the control } \\
\text { group }\end{array}$ \\
\hline $\begin{array}{l}\text { Grealish, L., } \\
\text { Lomasney, A., \& } \\
\text { Whiteman, B. }\end{array}$ & 2000 & $\begin{array}{l}\text { Analyze the impact of } \\
\text { massage therapy in } \\
\text { pain, nausea and } \\
\text { relaxation }\end{array}$ & randomized & EVA. & $\begin{array}{l}87 \text { cancer } \\
\text { patients }\end{array}$ & $\begin{array}{l}\text {-Immediate Reduction } \\
\text { of pain, nausea and } \\
\text { relaxation }\end{array}$ \\
\hline $\begin{array}{l}\text { Toth, M., Kahn, } \\
\text { J., Walton, T., } \\
\text { Hrbek, A., } \\
\text { Eisenberg, D., \& } \\
\text { Russell, P. }\end{array}$ & 2003 & $\begin{array}{l}\text { Evaluate the effect of } \\
\text { massage therapy in } \\
\text { pain and anxiety }\end{array}$ & pilot study & $\begin{array}{l}\text { Pain, anxiety } \\
\text { (VAS) and quality } \\
\text { of life (QOL) }\end{array}$ & $\begin{array}{l}26 \text { cancer } \\
\text { patients with } \\
\text { metastases }\end{array}$ & $\begin{array}{c}\text {-Decreased pain of } \\
5.50 \text { to } 3.83 \\
\text {-Increasing the anxiety } \\
\text { of } 3.83 \text { to } 4.75\end{array}$ \\
\hline $\begin{array}{l}\text { Post-White, J., } \\
\text { Kinney, M. E., } \\
\text { Savik, K., Gau, J. } \\
\text { B., Wilcox, C., \& } \\
\quad \text { Lerner, I. }\end{array}$ & 2003 & $\begin{array}{l}\text { Determine whether the } \\
\text { therapeutic massage } \\
\text { and touch are more } \\
\text { effective } \\
\text { than the standard } \\
\text { treatment in reducing } \\
\text { symptoms of anxiety, } \\
\text { mood disorders, pain, } \\
\text { nausea and fatigue and } \\
\text { increasing relaxation } \\
\text { and satisfaction }\end{array}$ & randomized & $\begin{array}{l}\text { BPI (Brief Pain } \\
\text { Index); BNI (Brief } \\
\text { Nausea Index); } \\
\text { POMS (Profile of } \\
\text { Mood States) }\end{array}$ & 164 patients & $\begin{array}{l}\text {-Reduced levels of } \\
\text { anxiety, pain with } \\
\text { decreased use of pain } \\
\text { relievers, blood } \\
\text { pressure, heart rate and } \\
\text { breathing }\end{array}$ \\
\hline $\begin{array}{l}\text { Soden, K., } \\
\text { Vincent, K., \& } \\
\text { Craske, S. }\end{array}$ & 2004 & $\begin{array}{c}\text { Evaluate the } \\
\text { effectiveness of the } \\
\text { massage to decrease } \\
\text { pain, anxiety, } \\
\text { depression, sleep } \\
\text { pattern and improve the } \\
\text { quality of life }\end{array}$ & randomized & $\begin{array}{l}\text { EVA, Verran and } \\
\text { Snyder-Halpern } \\
\text { (VSH) (scale of } \\
\text { sleep), hospital } \\
\text { anxiety and } \\
\text { depression scale } \\
\text { (HAD) and the list } \\
\text { of Symptoms } \\
\text { Rotterdam } \\
\text { (RSCL). }\end{array}$ & $\begin{array}{l}42 \text { cancer } \\
\text { patients }\end{array}$ & $\begin{array}{c}\text { No significant } \\
\text { differences in terms of } \\
\text { improvement in pain } \\
\text { management, anxiety } \\
\text { or quality of life. } \\
\text {-Improved sleeping } \\
\text { patterns } \\
\text {-Reduction of } \\
\text { depression in the } \\
\text { massage group }\end{array}$ \\
\hline $\begin{array}{l}\text { Hernandez-Reif, } \\
\text { M., Ironson, G., } \\
\text { Field, T., Hurley, } \\
\text { J., Katz, G., \& } \\
\text { Diego, M. }\end{array}$ & 2004 & $\begin{array}{l}\text { Evaluate the effect of } \\
\text { massage therapy in } \\
\text { anxiety, mood swings } \\
\text { and depression. }\end{array}$ & experimental & $\begin{array}{l}\text { State Trait Anxiety } \\
\text { Inventory (STAI); } \\
\text { Profile of Mood } \\
\text { States (POMS); } \\
\text { symptom } \\
\text { Checklist-90-R } \\
\text { (SCL-90-R) }\end{array}$ & $\begin{array}{l}34 \text { women with } \\
\text { breast cancer }\end{array}$ & $\begin{array}{l}\text {-Minimization in } \\
\text { anxiety, depressed } \\
\text { mood and anger in the } \\
\text { short term; } \\
\text {-Minimization, } \\
\text { long-term, depression }\end{array}$ \\
\hline
\end{tabular}




\begin{tabular}{|c|c|c|c|c|c|c|}
\hline $\begin{array}{l}\text { Cassileth, B., \& } \\
\text { Vickers, A. }\end{array}$ & 2004 & $\begin{array}{l}\text { Evaluate the effect of } \\
\text { massage therapy in } \\
\text { pain, fatigue, stress/ } \\
\text { anxiety, nausea and } \\
\text { depression. }\end{array}$ & $\begin{array}{c}\text { almost- } \\
\text { experimental }\end{array}$ & EVA & $\begin{array}{l}1290 \text { cancer } \\
\text { patients }\end{array}$ & $\begin{array}{l}\text {-Reduction of pain, } \\
\text { fatigue, stress, anxiety, } \\
\text { nausea and depression } \\
\text { approximately } 50 \% \\
\text { and in the same clinic } \\
\text { improved } 10 \% \text { more } \\
\text { than in the relocation } \\
\text { and more durability. }\end{array}$ \\
\hline $\begin{array}{l}\text { Deng, G., \& } \\
\text { Cassileth, B. }\end{array}$ & 2005 & $\begin{array}{l}\text { Evaluate the effect of } \\
\text { massage therapy in the } \\
\text { relief of symptoms }\end{array}$ & prospective & EVA & $\begin{array}{l}230 \text { cancer } \\
\text { patients }\end{array}$ & $\begin{array}{l}\text {-Decrease in the } \\
\text { incidence of muscle } \\
\text { fatigue, anxiety, } \\
\text { depression, rescue } \\
\text { analgesic consumption } \\
\text { and improved } \\
\text { circulatory and } \\
\text { respiratory pattern. }\end{array}$ \\
\hline $\begin{array}{l}\text { Ferreira, A., \& } \\
\text { Lauretti, G. }\end{array}$ & 2007 & $\begin{array}{l}\text { Evaluate the effects of } \\
\text { therapeutic massage in } \\
\text { the control of pain }\end{array}$ & experimental & $\begin{array}{l}\text { Pain (EAN) and } \\
\text { quality of life } \\
\text { (EORTC } \\
\text { QLC-C30) }\end{array}$ & $\begin{array}{l}34 \text { cancer } \\
\text { patients }\end{array}$ & $\begin{array}{l}\text {-Decrease in } \\
\text { consumption of } \\
\text { morphine }\end{array}$ \\
\hline $\begin{array}{l}\text { Wilkinson, S., } \\
\text { Love, S., } \\
\text { Wesrcombe, A., } \\
\text { Gambles, M., } \\
\text { Burgess, C., } \\
\text { Cargill, A., et al. }\end{array}$ & 2007 & $\begin{array}{l}\text { Assess the } \\
\text { effectiveness of care } \\
\text { with massage } \\
\text { the management of } \\
\text { anxiety and depression }\end{array}$ & randomized & $\begin{array}{l}\text { subscale of State } \\
\text { Anxiety Inventory } \\
\text { (SAI), Centre for } \\
\text { Epidemiological } \\
\text { Studies } \\
\text { Depression } \\
\text { (CES-D) }\end{array}$ & $\begin{array}{l}288 \text { cancer } \\
\text { patients }\end{array}$ & $\begin{array}{l}\text {-There were no } \\
\text { significant differences } \\
\text { in improvement of } \\
\text { anxiety and depression; } \\
\text {-The anxiety improved } \\
\text { self-report for patients } \\
\text { who received massage } \\
\text { therapy. This } \\
\text { relationship did not } \\
\text { exist for the self-report } \\
\text { of depression. }\end{array}$ \\
\hline $\begin{array}{c}\text { Billhut, A., } \\
\text { Bergbom, I., \& } \\
\text { Stenes-Victorin, } \\
\text { E. }\end{array}$ & 2007 & $\begin{array}{l}\text { Evaluate the effect of } \\
\text { massage therapy in } \\
\text { levels of nausea, } \\
\text { anxiety and depression }\end{array}$ & randomized & $\begin{array}{l}\text { Eva for nausea and } \\
\text { for the remaining } \\
\text { variables used the } \\
\text { HADS }\end{array}$ & $\begin{array}{l}39 \text { women with } \\
\text { breast cancer } \\
\text { doing } \\
\text { chemotherapy }\end{array}$ & $\begin{array}{l}\text {-Significant Reduction } \\
\text { of nausea in the } \\
\text { experimental group; } \\
\text {-There were no } \\
\text { differences between } \\
\text { anxiety and depression } \\
\text { in both groups. }\end{array}$ \\
\hline $\begin{array}{l}\text { Kutner, S., Smith, } \\
\text { M., Corbin, L., } \\
\text { Kemphill, 1., } \\
\text { Benton, K., \& } \\
\text { Mellis, K. }\end{array}$ & 2008 & $\begin{array}{c}\text { Evaluate the } \\
\text { effectiveness of the } \\
\text { massage to decrease } \\
\text { pain } \\
\text { and distress of } \\
\text { symptoms and improve } \\
\text { quality of life } \\
\text { Evaluate the } \\
\text { effectiveness of } \\
\text { therapeutic massage in } \\
\text { improving the quality } \\
\text { of life, pain, stress, } \\
\text { suffering }\end{array}$ & randomized & $\begin{array}{c}\text { Memorial Pain } \\
\text { Assessment Card; } \\
\text { Brief Pain } \\
\text { Inventory [BPI]; } \\
\text { McGill Quality of } \\
\text { Life } \\
\text { Questionnaire; } \\
\text { Memorial } \\
\text { Symptom } \\
\text { Assessment Scale }\end{array}$ & $\begin{array}{l}380 \text { advanced } \\
\text { cancer patients }\end{array}$ & $\begin{array}{l}\text {-Immediate } \\
\text { improvements in mood } \\
\text { and in pain, with more } \\
\text { relevance in the } \\
\text { experimental group. } \\
\text {-In the long term, there } \\
\text { were no statistical } \\
\text { differences corroborate } \\
\text { the improvement in } \\
\text { quality of life, pain, } \\
\text { stress, suffering and in } \\
\text { decreasing the use of } \\
\text { painkillers. }\end{array}$ \\
\hline $\begin{array}{l}\text { Currin, J.; } \\
\text { Meister. E. }\end{array}$ & 2008 & $\begin{array}{l}\text { Analyze the impact of } \\
\text { massage therapy in } \\
\text { pain, physical and } \\
\text { emotional } \\
\text { desnconforto and } \\
\text { fatigue }\end{array}$ & Not randomized & & $\begin{array}{l}251 \text { cancer } \\
\text { patients }\end{array}$ & $\begin{array}{l}\text { - Decrease of pain, } \\
\text { discomfort, emotional } \\
\text { and physical fatigue. }\end{array}$ \\
\hline Young, C. & 2008 & & experimental & & $\begin{array}{l}28 \text { terminal } \\
\text { cancer }\end{array}$ & $\begin{array}{l}\text {-Decreased pain and } \\
\text { depression for the } \\
\text { experimental group. }\end{array}$ \\
\hline $\begin{array}{l}\text { Downey, L., } \\
\text { Diehr, P., } \\
\text { Standish, L., } \\
\text { Patrick, D., } \\
\text { Kozak, L., Fisher, } \\
\text { D., et al. }\end{array}$ & 2009 & $\begin{array}{l}\text { Evaluate the effect of } \\
\text { massage therapy on } \\
\text { quality of life and pain }\end{array}$ & Randomized & $\begin{array}{l}\text { MSAS (Memorial } \\
\text { Symptom } \\
\text { Assessment Scale) }\end{array}$ & 167 patients & $\begin{array}{l}\text {-Reduction of pain, } \\
\text { however, was not } \\
\text { statistically significant }\end{array}$ \\
\hline
\end{tabular}




\begin{tabular}{|c|c|c|c|c|c|c|}
\hline $\begin{array}{l}\text { Jane, S. W., } \\
\text { Wilkie, D. J., } \\
\text { Gallucci, B. B., } \\
\text { Beaton, R. D., \& } \\
\text { Huang, H. Y. }\end{array}$ & 2009 & $\begin{array}{c}\text { Evaluate the } \\
\text { effectiveness of } \\
\text { massage in reducing } \\
\text { the levels of pain }\end{array}$ & $\begin{array}{c}\text { Quasi- } \\
\text { experimental }\end{array}$ & $\begin{array}{l}\text { VAS (anxiety) } \\
\text { MSF_MPQ } \\
\text { (Short-Form } \\
\text { Mc-Grill Pain } \\
\text { Questionnaire): } \\
\text { BPI (Brief Pain } \\
\text { Inventory) }\end{array}$ & $\begin{array}{l}\text { Patients with } \\
\text { metastases bone }\end{array}$ & $\begin{array}{c}\text { Immediate effect } \mathrm{p}= \\
0.001 \\
\text { Medium effect } \mathrm{p}< \\
0.000 \\
\text { Long effect } \mathrm{p}=0.04\end{array}$ \\
\hline $\begin{array}{l}\text { Adams, R., } \\
\text { White, B., \& } \\
\text { Beckett, C. }\end{array}$ & 2010 & $\begin{array}{l}\text { Evaluate the effect of } \\
\text { massage therapy in the } \\
\text { levels of pain }\end{array}$ & $\begin{array}{l}\text { qualitative and } \\
\text { quantitative }\end{array}$ & $\begin{array}{c}\text { EVA } \\
\text { - interview }\end{array}$ & $\begin{array}{l}53 \text { cancer } \\
\text { patients }\end{array}$ & $\begin{array}{c}\text {-The pain level } \\
\text { decreases from } 5.18 \text { to } \\
2.33 \text { after the } \\
\text { intervention of the } \\
\text { massage. } \\
\text {-Through the } \\
\text { qualitative data } \\
\text { describe these illustrate } \\
\text { relevant improvements } \\
\text { in terms of total pain, } \\
\text { emotional well-being, } \\
\text { relaxation and sleep } \\
\text { patterns. }\end{array}$ \\
\hline $\begin{array}{l}\text { Sui-Whi, J., } \\
\text { Wilkie, D., } \\
\text { Gallucci, B., } \\
\text { Beaton, R., \& } \\
\text { Huang, H.-Y. }\end{array}$ & 2011 & $\begin{array}{l}\text { Evaluate the } \\
\text { effectiveness of the } \\
\text { massage of pain, } \\
\text { anxiety and vital signs }\end{array}$ & Randomized & $\begin{array}{l}\text { (BPI-VAS) pain, } \\
\text { anxiety, sleep, } \\
\text { relaxation and } \\
\text { distress used VAS }\end{array}$ & $\begin{array}{l}36 \text { Patients with } \\
\text { metastases bone }\end{array}$ & $\begin{array}{l}\text { Effective in the short } \\
\text { and in the long term } \\
\text { with regard to pain and } \\
\text { anxiety, } \\
\text { There were no } \\
\text { significant effects that } \\
\text { could corroborate the } \\
\text { changes in heart rate } \\
\text { and mean arterial } \\
\text { pressure. }\end{array}$ \\
\hline
\end{tabular}

\section{Discussion}

The results described above emphasize the current need to increase the empirical evidence as well as raise awareness of the benefits associated with this type of interventions that is carried out by nursing staff-therapeutic massage, focusing particularly on the level of patients with oncological pathology.

However, most studies in this systematic review enhance the effect of massage therapy on decreasing levels of pain and the intensity of some outbreaks that cause discomfort such as: providing relaxation, pleasure, avoiding physical problems, releasing emotional blocks, easing pain. In this particular case, it is up to the nurse to try to reduce the pain, anxiety, depression and discomfort.

Regarding pain, it was found on the basis of the described studies above, that the results converge because massage therapy decreases pain levels in some very significantly (Weinrich \& Weinrich[26]; Ferrell-Torry \& Glick[13]; Grealish, Lomasney, \& Whiteman[14]; Wilkie et al.[27]; Toth et al. [25]; Post-White et al.[21]; Cassileth \& Vickers[6]; Currin \& Meister[8]; Young[29]; Jane et al. [16]; Adams, White \& Beckett[1]; Sui-Whi, et al.[24]) and in others not so much (Deng \& Cassileth[9]; Ferreira \& Lauretti[12]; Kutner et al.[17]). We also note that there is the possibility of certain studies support that massage therapy causes patients to reduce the use of painkillers and recourse to SOS (Post-White, Kinney, Savik, Gau \& Lerner[21]; Deng \& Cassileth[9]), However, it was concluded that the differences are not that significant (Ferreira \& Lauretti[12]; Kutner et al.[17]).

In terms of anxiety and depression, there were also contradictory results because some have revealed positive effects that patients feel in a short term (Post-White, Kinney, Savik, Gau \& Lerner[21]; Hernandez-Reif, Ironson, Field, Hurley, Katz \& Diego[15]; Cassileth \& Vickers[6]; Deng \& Cassileth[9]; Young[29]; Jane et al. [16]), other long-term (Soden, Vincent, Craske[23]; Hernandez-Reif et al.[15]) and others did not reveal any effects (Ahles et al.[2]).

There are also discrepancies about the other areas of nursing, with respect to the effectiveness of massage therapy, the level of nausea, as some studies consider that massage therapy has benefits (Ahles et al.[2]; Grealish, Lomasney, \& Whiteman[14]; Cassileth \& Vickers[6]) and others don't mention them (Ahles et al.[2]; Post-White et al. [21]).

However, it was found that this intervention has obtained positive results, associated with decreased vital signs due to the relaxation promoted (Ferrell-Torry \& Glick[13]; Post-White et al.[21]; Deng \& Cassileth[9]), in the depressed mood and anger (Hernandez-Reif, Ironson, Field, Hurley, Katz \& Diego[15]; Kutner et al.[17]), on muscle fatigue (Cassileth \& Vickers[6]; Deng \& Cassileth[9]; Currin \& Meister[8]), in stress (Cassileth \& Vickers[6]) and the level of emotional well-being and sleep patterns (Soden et al.[23]; Adams et al.[1]). There were no statistical differences that could corroborate the improvement in quality of life, stress and suffering (Soden et al.[23]; Kutner et al.[17]), justifying 
the interest of this study.

\section{Conclusions}

Although the analysis of the results was contradictory in many cases and showed positive and negative or neutral data, the purpose of our study allowed us to conclude that massage therapy has beneficial effects. Being so, in a short term, the level of emotional well-being and relaxation increases, as physical and emotional discomfort, depressed mood, sleep patterns and stress decreases. The levels of quality of life and suffering are contradictory, reporting to future investigations continuity perspective.

Through this study, we found the need to step up the research in the field of nursing, broadening the field of nurses, leading to effective therapeutic interventions carried out by these professionals so that we can control and lessen the anxiety and depression.

The nurse has an important role in the patients' recovery, highlighting their feelings and contributing to improve their self-esteem. In this sphere, the massage therapy intervention is essential, as the constant contact of the nurse with the patient encourages the implementation of these actions in order to relieve pain, promote common assistance and improve one's quality of life.

It was noted also that the use of massage therapy is a reality in the universe of human health, nurses increasingly resorting to this type of interventions that had been used for a long time for the patient's comfort. Our role as investigators and researchers is to establish scientifically the effects and benefits of this intervention, in order to add them to the non-pharmacological therapies that are already incorporated in the current health care system.

It is well known that even with the lack of research in this area, the nurses in their day-to-day work already use some therapies for pain control, such as relaxation techniques, cutaneous stimulation (massage, heat/cold, Transcutaneous electrical stimulation), etc..

It was found that the relaxation promotes the reduction of these factors, especially the muscle tension, improving the pain, because muscle contraction contributes to exacerbation of pain, focusing on the nerve endings, especially in chronic pain.

With the preparation of this study, we realised that massage therapy decreases total pain levels, both in a short or long term, and that, according to some authors, decreased the use of analgesics and the consumption of painkillers.

It seems that with the implementation of the relaxation massage, it can actually help rebalancing the body. However, most complementary therapies lead people to submit the relaxation response. Such techniques are related to existing interaction between pain, muscle tension and anxiety, because a patient with pain often presents feelings of apprehension and fear, leading to muscle tension which in turn worsens the pain.
It is important to note that the additional practices that can be used as non-pharmacological treatment of pain are two groups: techniques or methods carried out by nurses in the nursing consultation and that require expertise or professional qualification.

The care factors depend on the humanistic expectation, associated with the scientific knowledge and concept of mutuality that should exist between the nurse and the patient. That is why the nursing staff has the duty to be aware of the patient's complaints. The body pain that is felt by the patient should always be monitored, so that his story is as improved and real as possible, regarding the evidence of pain and description of its intensity in order to have a combat intervention as efficient as possible.

One of the nurse's contributions is the emphasis on care practice as interpersonal, based on factors that result in the satisfaction of human needs, promoting health, as well as an individual and family growth. It is essential to understand the environment as favouring the personal development and integrated in the biophysical and human behavioural knowledge.

Finally, and still on the basis of the results obtained, we also suggest the development of more research in order to give greater consistency to empirical effects of massage intervention, cancer patients and so contributing to the practice of nursing excellence based on evidence.

\section{REFERENCES}

[1] Adams, R., White, B., \& Beckett, C. (2010). The effects os massage therapy on pain management in the acute care setting. International Journal of Therapeutic Massage \& Bodywork, 3(1), 4-11.

[2] Ahles, T., Tope, D., Pinkson, B., Walch, S., Hann, D., Whedon, M., Silberfarb, P. (1999). Massage therapy for patients undergoing autologous bone marrow transplantation. Journal pf pain \& Sympton Management, 18(3), 157-163.

[3] Almeida, M. d., \& Duarte, S. F. (2000). Massagem dorsal de bem-estar e de conforto. Referência, 75-78.

[4] Bair, M., Robinson, R., Katon, W., Kroenke, K. (2003). Depression and Pain Comorbidity- A Literature Review, Arch Intern med., 163, 2433-2445

[5] Billhut, A., Bergbom, I., \& Stenes-Victorin, E. (2007). Massage relieves nausea in women with breast cancer who are undergoing chemotherapy. Journal of Alternative and Complementary Medicine, 13(1), 53-57.

[6] Cassileth, B., \& Vickers, A. (2004). Massage therapy for sympton outcome study at a major cancer center. Journal Pain Sympton Manage, 28(3), 244-249.

[7] Castro, E., Scorza, A. \& Chem, C. (2011). Qualidade de vida e indicadores de ansiedade e depressão de pacientes com cancro colo-rectal. Psic., Saude \& Doenças, 12(1), 131-142. 
[8] Currin, J., \& Meister, E. (2008). A hospital-based intervention using massage to reduce distress among oncology patients. Cancer nurs, 31(3), 214-221.

[9] Deng, G., \& Cassileth, B. (2005). Integrative oncology: complementary therapies for pain, anxiety, and mood disturbance. Cancer journal for clinicians, 55(2), 109-116.

[10] Direção Geral de Saúde (DGS) (2001). Plano Nacional de Luta Contra a Dor. Portugal: Direção Geral de Saúde, 60 p.

[11] Downey, L., Diehr, P., Standish, L., Patrick, D., Kozak, L., Fisher, D., .. . Lafferty, W. (2009). Might massage pr guided meditation "means to a better end"?. Primary outcomes from an efficacy trial with patients at the end of life. Journal of palliative care, 25(2), 100-108.

[12] Ferreira, A., \& Lauretti, G. (2007). Estudo dos efeitos da massoterapia no alívio da dor e na melhoria da qualidade de vida em pacientes oncológicos sob cuidados paliativos. Revista Dor, 8(2), 983-993.

[13] Ferrell-Torry, A., \& Glick, O. (1993). The use of therapeutic massage as a nursing intervention to modify anxiety and the perception of cancer pain. Cancer nurs, 16(2), 93-101.

[14] Grealish, L., Lomasney, A., \& Whiteman, B. (2000). Foot massage: a nursing intervention to modify the distressing symptoms of pain and nausea in patients hospitalized with cancer. Cancer Nursing, 23(3), 237-243.

[15] Hernandez-Reif, M., Ironson, G., Field, T., Hurley, J., Katz, G., \& Diego, M. (2004). Breast cancer functions following massage therapy. Journal of psychosomatic research, 57(1), 45-52.

[16] Jane, S. W., Wilkie, D. J., Gallucci, B. B., Beaton, R. D., \& Huang, H. Y. (2009). Effects of a full-body massage on pain intensity, anxiety, and physiological relaxation in Taiwanesse patients with mestastasic bone pain: a pilot study. Journal of Pain Sympton Manage, 37(4), 754-763.

[17] Kutner, S., Smith, M., Corbin, L., Kemphill, 1., Benton, K., \& Mellis, K. (2008). Massage Therapy versus simple touch to improve and mood in patients with advanced cancer: a randomized trial. Annal of Internal Medicine, 149(6), 369-379.

[18] Meleis, Afaf (2012). Theoretical Nursing development \& progress, Philadelphia: Wolters Kluwer.
[19] Ordem dos Enfermeiros (2008). Dor Guia de Boas Práticas, Portugal: Ordem dos Enfermeiros.

[20] Ordem dos Enfermeiros (2011). Regulamento de competências especificas do enfermeiro especialista em enfermagem em pessoa em situação crónica e paliativa, Portugal: Ordem dos Enfermeiros.

[21] Post-White, J., Kinney, M. E., Savik, K., Gau, J. B., Wilcox, C., \& Lerner, I. (2003). Therapeutic massage and healing touch imporve symptons in cancer. Intergrative Cancer Therapies, 2(4), 332-344.

[22] Runnig, A., Shreffler-Grant, J., \& Andrews, W. (2008). A survey os hospices use of complementary. Journal of Hospice and palliative nursing, 10(5), 304-312.

[23] Soden, K., Vincent, K., \& Craske, S. (março de 2004). A randomized controlled trial of aromatherapy massage in a hospice setting. Palliative medicine, 18(2), 87-92.

[24] Sui-Whi, J., Wilkie, D., Gallucci, B., Beaton, R., \& Huang, H.-Y. (2011). Effects os massage on pain, mood status, relaxation, and sleep in Taiwanese patients with metastasic bone pain. A randomized clinical trial. Pain, 152(10), 2432-2442.

[25] Toth, M., Kahn, J., Walton, T., Hrbek, A., Eisenberg, D., \& Russell, P. (2003). Therapeutic massage, intervention for hospitalized patients with cancer. Alternative \& complementary therapies, 9(3), 117-124.

[26] Weinrich, S., \& Weinrich, M. (1990). The effect of massage on pain in cancer patients. Applied Nursing Research, 3(1), $140-145$.

[27] Wilkie, D., Kampbell, J., Cutshall, S., Halabisky, H., Harmon, H., Johnson, L., . . . Rake-Marona, M. (2000). Effects of massage on pain intensity, analgesics and quality of life in patients with cancer pain: a pilot study of a randomized clinical trial conducted with hospice care delivery. Hospice Journal - Physical, Psychosocial, \& Pastoral Care of the Dying, 15(3), 31-53.

[28] Wilkinson, S., Barnes, K., \& Store, L. (2008). Massage for sympton relief in patientes with cancer: systematic review. Journal of Advanced nursing, 63(5), 430-439.

[29] Young, C. (agosto de 2008). Effects of aroma hand massage on pain, state anxiety and depression in hospice patients with terminal cancer. Journal of Korean Academy of Nursing, 38(4), 493-502. 